\title{
EXPERIMENTAL STUDY ON CHARACTERIZATION AND POLLUTION POTENTIAL OF CONTAMINATED CHROMIUM HAZARDOUS WASTE
}

\author{
Madhusudhan Rao', M. Gopal Naik ${ }^{2}$, Aadhi Naresh ${ }^{3}$ \\ ${ }^{1}$ Research Scholar, padmadhusudhan@yahoo.co.in \\ ${ }^{2}$ Professor, mgnaikc@gmail.com \\ ${ }^{3} P G$ Student, ayyaure@gmail.com
}

\begin{abstract}
Although many researchers are working on pollution potential and containment of hazardous waste, still there is a need for investigation of its characterization, influence on ground and surface water, its treatment and containment especially on chemical sludges containing heavy metals like chromium which is potential carcinogenic. An industry in Nalgonda District by name M/s. Deccan Chromates Limited situated at Damarcherla (V), Telangana State has left the extremely hazardous hexavalent chromium sludge, a life-threatening compound. This waste is classified under Schedule - II Hazardous Waste substances of the Hazardous Waste (Management, Handling and Transboundary Movement) Rules, 2008. Exposure to about 53,000 tons of chromium sludge can lead to cancer and devastating consequences for the people around it. As of now there is no contingency plan to dispose of the hazardous waste. The accumulation of chromium is contaminating the agricultural fields and water sources. The chemical factory was set up in 1998 to produce Sodium Dichromate, which is used in paints and for leather tanning. During its 10 year existence, the factory dumped the hazardous waste matter in an area of about 3 acres before the plant was shut-down in 2008 leaving the villages in the vicinity facing an alarming crisis. People who inhale the hexavalent chromium over long periods run the risk of contracting lung cancer. Repeated or prolonged exposure can cause sores and ulcers on the feet and in fingers. Hexavalent chromium can cause damage to the respiratory tract, lungs, kidneys, liver and the gastro-intestinal, immune and blood and reproductive systems. Although it has been 6 years that the factory has ceased operating, toxic waste from the plant continues to pollute both Musi and Krishna Rivers. Thousands of sheep and goat have been affected after drinking the contaminated water. The Toxic waste has deeply affected the agricultural lands. Any mishap that occurs can be very damaging. Thus, the toxic waste poses threat to thousands due to cancer-causing chromium left untreated by defunct factory in Nalgonda District. Here an attempt is made to study and highlight the pollution potential of the chrome sludge disposed by the industry, its characterization, treatment for making it non hazardous, implementation of the treatment process on plant scale and techniques of proper engineered landfill with the phases of site selection, design, construction, operation, environmental monitoring, closure and post closure for containment of the hazardous waste.
\end{abstract}

Keywords: Contaminated Chromium Hazardous Waste, TCLP Analysis, Geosynthetic Liners

\section{INTRODUCTION}

Under the influence of industrialization, globalization and technology like the rest of the population in other parts of the world, the ordinary Indian has drifted tangentially away from his primary, ethical responsibility to protect and care for the well-being of the natural world. In the recent year's public awareness of environmental issues has immensely increased, around the world and in India too - whether it is cutting down forests for the ever expanding townships in hilly and forest areas, building large projects, or more mundane affairs like industrial sludge containments. The emphasis on waste management has gained momentum only now that its deleterious effects on climate change have begun to fret the world. New technologies and methods are being devised to collect, segregate, recycle and land fill hazardous waste with careful study of their environmental impact. The advent of geosynthetics has opened a world of opportunities for proper containment of hazardous wastes. As per MoEF( Ministry of Environment and Forest) report prepared on hazardous waste, in India too, for example, Hazardous Waste Management and Handling Rules were introduced in the year 1989 (MoEF, 1989) and amended in 2008, yet the response towards their implementation has remained very poor. The report further indicates that due to the liberalized policy the pace of industrialization has been accelerated, which has resulted in increasing amounts of industrial hazardous wastes. Due to inadequate policy implementation and technological measures, appropriate disposal of these wastes continues to remain a daunting issue of environmental concern in India. The Central Pollution Control Board (CPCB, 2001), Ministry of Environment and Forests, Government of India has brought out the Criteria for Hazardous Waste Landfill, which include (i) Site Selection, (ii) Site investigation criteria, (iii) Planning and design criteria, (iv) Landfill liner criteria and cover criteria, (v) Construction and operation criteria, (vi) Inspection, Monitoring and (vii) Post - closure criteria. 
Subsequently, the Manual for Design, Construction and Quality Control of Liners and Covers for Hazardous Waste Landfills (CPCB, 2002) was published. It deals with the principles of design, construction and quality control of various components of liners and covers used for the secured landfill for disposal of hazardous landfills. Mitchell and Madsen (1987) have investigated the interaction between chemicals and clay soils. The studies have consistently shown that the changes in hydraulic conductivity can be related (Quantitatively) to changes in thickness of diffuse double layer of cations that surrounds the negatively charged clay

particles. An increase in thickness of diffuse double layer reduces hydraulic conductivity. Conversely (and of greater concern), shrinkage of the diffuse double layer tends to increase hydraulic conductivity. Cervinkova et al. (2007) made another notable contribution to the problem of heavy metal leaching from stabilization/ solidification hazardous waste. They used hazardous waste containing heavy metals, mainly cadmium and nickel; these substances are not released even from the untreated waste when the aqueous leaching procedure is applied. Therefore, acidic leaching test was used for the valuation of toxicity as heavy metals leached much faster under acidic conditions. These studies contain different experiment protocols and various mathematical models; most of them are based on the diffusion processes within the matrix of stabilized waste (Andres et al., 1995; Moszkowicz et al., 1998; Onguro and Inyang, 2003). Rajaram (2002) presented a waste disposal project in India to highlight the techniques of proper site selection, design and construction quality assurance. Cervinkova et al. (2005) developed a long-term leaching test using five buffers acetic acid - sodium acetate with different $\mathrm{pH}$. Then a mathematical model was developed to analyze the data. Using the kinetics of the leaching process and the mathematical model, the leaching test results can be extrapolated for alkaline environments. Then the mathematical model was used to evaluate the long-term (several thousands of years) release of hazardous substances from the treated hazardous waste under alkaline environment.

Based on the discussion, the specific objectives are made as follows:

- To investigate and carry out detailed sampling of chromium sludge disposed by an industry manufacturing chromium chemicals from chromite ore at various depths using various site exploration engineering techniques like open excavation, auger and shell boring.

- To carryout waste characterization and pollution potential of the chrome waste by conducting experimental studies on the samples collected for 33 parameters including 11 heavy metals using physical analysis (physical state, color and texture, specific gravity, bulk density, moisture, organic content, extractable lipophilic content), chemical analysis (chromium hexavalent, mercury and its compounds, cadmium, arsenic, and its compounds, chromium (III) compounds, copper and its compounds, lead and its compounds, molybdenum compounds, nickel compounds, zinc compounds, barium compounds, except barium sulphate), Toxicity Characteristic Leaching
Procedure (TCLP) analysis (chromium) and acceptance criteria analysis of Hazardous waste into secured land fill (pH-corrosivity, arsenic, lead, cadmium, chromium hexavalent, total chromium, copper, nickel, mercury, zinc, fluorides, ammonia, cyanide, nitrates).

- To develop a pretreatment process for hexavalent chrome waste generated from chromium chemicals manufacturing process and to evolve a chemical reducing process by conducting laboratory experiments on the quantity of Ferrous Sulphate required to treat the hazardous residue resulting in bringing the hexavalent chromium in TCLP extract to below detectable limits and plant scale.

\section{METHODOLOGY}

\subsection{Techniques used for Containment of Hazardous}

\section{Waste}

Wastes accepted for disposal at TSDF (Treatment, Storage and Disposal, Facility) shall confirm the requirements for landfill as per Schedule and guidelines of Central Pollution Control Board (2008) for Physical Analysis, Chemical Analysis, Toxicity Characteristic Leaching Procedure (TCLP) Analysis and Acceptance Criteria Analysis into secured land fill. The hazardous waste landfill (HW Landfill) techniques used for containment of hazardous waste in various countries were studied. The term hazardous waste landfill (HW Landfill) is used to designate a waste disposal unit designed and constructed with the objective of minimum impact to the environment. This term encompasses other terms such as "secured landfill", "engineered landfill", "waste mounds", "waste piles" etc., as per criteria for hazardous landfills (CPCB, 2001).

A landfill design life will comprise of an 'active' period and a 'closure and post-closure' period. The 'active' period shall comprise of the period for which waste filling is in progress at the landfill and typically range from 10 to 25 years depending of the availability of land area. The 'closure and post-closure' period for which a landfill will be monitored and maintained shall be 30 years after the 'active period' is completed.

\subsection{Geotechnical Properties of Wastes}

\subsubsection{Permeability}

The hydraulic conductivity of compacted wastes is an important physical property that to a large extent, governs the movement of liquids and gases in a landfill. The coefficient of permeability is normally written as:

$$
\mathrm{K}=\mathrm{Cd}^{2} \frac{\Upsilon}{\mu}=\mathrm{k} \frac{\Upsilon}{\mu}
$$

$\mathrm{K}=$ coefficient of permeability

$\mathrm{C}=$ dimensionless constant or shape factor

$\mathrm{d}=$ average size of pores

$\Upsilon=$ specific weight of water

$\mu=$ dynamic viscosity of water

$\mathrm{k}=$ intrinsic permeability 
The term $\mathrm{Cd}^{2}$ is known as the intrinsic permeability. The intrinsic permeability depends solely on the properties of the solid material, including pore size distribution, tortuosity, specific surface, and porosity. Typical values for the intrinsic permeability for compacted solid waste in a landfill are in the range between $10^{-11}$ and $10^{-12} \mathrm{~m}^{2}$ in the vertical direction and about $10^{-10} \mathrm{~m}^{2}$ in the horizontal direction. The average permeability of refuse can be indirectly estimated using the above equation 1 .The permeability correlates well with unit weight.

\subsubsection{Compressibility}

The settlement characteristics of waste are important to investigate and understand as excessive or differential settlement can lead to the fracture or breakage of gas or leachate extraction pipes, which can then lead to a dangerous buildup of landfill gas or can cause saturation of the waste mass. Differential settlement can cause dramatic changes in the surface profiles of the finished landfill site, which are designed in the landfill license to allow water runoff. Excessive differential settlement can cause areas of depression that can lead to the formation of permanent water bodies; these in turn results in additional load to the waste and therefore increased differential settlement. The formation of a permanent water body on the surface of the landfill site will increase the amount of water percolating into the landfill site, resulting in more quantity of leachate to be dealt with.

It is a common practice to evaluate the compressibility of refuse by employing the theory of one dimensional consolidation. Under a load increase $\Delta \mathrm{p}$ in a layer of refuse with a thickness $\mathrm{H}_{\mathrm{i}}$ under an existing effective $\mathrm{p}_{\mathrm{o}}$, the settlement is estimated:

$$
\Delta=\mathrm{C}_{\mathrm{CR}} \mathrm{H}_{\mathrm{i}} \log \frac{\left(\mathrm{p}_{\mathrm{o}}+\Delta_{\mathrm{p}}\right)}{\mathrm{p}_{\mathrm{o}}}+\frac{\mathrm{H}_{\mathrm{i}}}{\mathrm{C}_{a}} \log \frac{\mathrm{t}_{2}}{\mathrm{t}_{1}}{ }^{(2)} \delta \stackrel{\text { ere }}{=}
$$$$
\begin{array}{lll}
\mathrm{p}_{\mathrm{r}} & \mathrm{t}_{1} & \delta= \\
& \text { settl }
\end{array}
$$

ement of layer of refuse with a thickness $\mathrm{H}_{\mathrm{i}}$

$\mathrm{C}_{\mathrm{CR}}=\left(\mathrm{C}_{\underline{c}}\right)=$ compression ratio, slope of stress

$1+\mathrm{C}_{\mathrm{c}}$ strain curve from semi log plot in the virgin

range

$\Delta_{\mathrm{p}}=$ increase in stress at midpoint at the layer due to the applied load,

$\mathrm{P}_{\mathrm{o}}=$ initial effective stress at midpoint at the layer due to the applied load

$\mathrm{C}_{\alpha}=$ coefficient of secondary compression

$\mathrm{t}_{1}=$ time for pseudo-primary (mechanical settlement) to occur, usually it is taken as one month for a 15 feet layer of refuse, and

$t_{2}=$ time for which settlement is computed, $t_{2}>t_{1}$

If no load is applied to the refuse fill, the fill would experience settlement due to many factors including: movement of particles into large voids; chemical reactions; dissolving of soluble substances by percolating groundwater or leachate; change in deformation properties with time; and plastic flow or creep. Settlement of landfill would also occur during construction of the landfill. Consider a projected height $\mathrm{h}_{1}$ completed in time $\mathrm{t}$, the average vertical effective stress $\sigma_{v a}$ is $\Upsilon_{1} h_{1} / 2$ where $\Upsilon_{1}$ is the unit weight of the waste.

The average constrained modulus is $\mathrm{D}$ and the average primary settlement of the refuse would amount to $11 \%$ of the projected height prior to its completion. The secondary settlement is given by $\mathrm{C}_{\alpha} \mathrm{h}_{1} \log \mathrm{t}$, where $\mathrm{t}$ is the average life of the landfill. For a typical t of 120 months (10 years), $\mathrm{C}_{\alpha}$ of 0.1 , the secondary compression may amount of $21 \%$ of the height. The total settlement is about $30 \%$. Estimates $\mathrm{C}_{\mathrm{CR}}$ values varied from 0.08 to 0.41 , from one dimensional consolidation test on waste of density of $600 \mathrm{~kg} / \mathrm{m}^{3}$ (initial void ratio of 2.86), Sargunan et al. (1986) have reported a compression index of 0.55 and secondary compression coefficient varying from 0.0036 to 0.005 for a landfill dump.

\subsubsection{Geosynthetic Liners}

Selection of liner material depends on hydraulic conductivity, chemical compatibility with leachate, landfill gas permeation, aging and durability characteristics, stress and strain characteristics, ease of installation etc. Three types of liners were considered for comparison.

- Soil Liner

- Geo Membrane liner

- Composite liner (Geo membrane liner overlying compacted clay liner)

Flow rate (Infiltration) through above liners can be calculated using following equations:

$\mathrm{Q}=\mathrm{k}_{\mathrm{s}} \mathrm{iA}$ (Soil liners) (darcy's Law)

$\mathrm{q}=\mathrm{C}_{\mathrm{B}} \mathrm{a}(2 \mathrm{gh})^{0.5}$ (Geomembrane Liners)

$\mathrm{q}=1.15 \mathrm{n}^{0.9} \mathrm{a}^{0.1} \mathrm{k}_{\mathrm{s}}^{0.74}$ (Composite with poor contact) (5)

$\mathrm{q}=0.21 \mathrm{n}^{0.9} \mathrm{a}^{0.1} \mathrm{k}_{\mathrm{s}}^{0.74}$ (Composite with good contact) (6)

Where

$\mathrm{Q}=\quad$ Flow rate $\left(\mathrm{m}^{3} / \mathrm{s}\right)$

$\mathrm{K}_{\mathrm{s}}=\quad$ Hydraulic conductivity of soil $(\mathrm{m} / \mathrm{s})$

$\mathrm{I}=$ hydraulic gradient $[(\mathrm{h}+\mathrm{d}) / \mathrm{d}]$

$\mathrm{H}=\quad$ liquid head $(\mathrm{m})$

$\mathrm{D}=\quad$ soil thickness $(\mathrm{m})$

$\mathrm{A}=\quad$ Area of soil $\left(\mathrm{m}^{2}\right)$

$\mathrm{C}_{\mathrm{B}}=0.6$ (flow coefficient)

$\mathrm{a}=$ Area of hole $\left(\mathrm{m}^{2}\right)$

$\mathrm{g}=$ Acceleration due to gravity $\left(\mathrm{m} / \mathrm{s}^{2}\right)$

\subsubsection{Geometric Consideration for Landfill Depth}

By geometric consideration, before selecting the geomembrane type, one must consider the desired solid volume to be contained versus the available land area, such siting calculation are geometric by nature and result is a required depth on the basis of assumed side slope angles. For a square or rectangular section with uniform side slope the general equation is

$\mathrm{V}=\mathrm{HLW}-\mathrm{SH}^{2} \mathrm{~L}-\mathrm{SH}^{2} \mathrm{~W}+2 \mathrm{~S}^{2} \mathrm{H}^{3}$

Where

$\mathrm{V}=$ the volume of landfill,

$\mathrm{H}=$ the height (i.e., depth of landfill at the centre),

$\mathrm{W}=$ the width at ground surface

$\mathrm{L}=$ the length of the ground surface, and

$\mathrm{S}=$ the slope ratio (horizontal to vertical) 
The equation (7) can be solved in a variety of ways and various design curves can be generated. Further it can be seen that to contain large volumes can easily require massive land areas and / or deep containment excavations. Usually the height of the landfill is between 5 to $20 \mathrm{~m}$.

\section{EXPERIMENTAL DATA AND ANALYSIS}

\section{1characterization Analysis}

The hazardous waste samples were collected dump wise viz., i) OD (Dump-1) i.e., old dump open to sky, ii) PD (Dump-2) i.e., processed dump open to sky and iii) SD (Dump-3) i.e., shed dump under covered shed. Total 15 samples were collected from dump-1 to cover the total area in different depths, 6 samples were collected from dump-2 to cover the area in depth wise and 6 samples were collected from dump-3 i.e. inside covered area to represent the total dump. Thus, 27 samples were collected at various depths varying from 0 to $9.144 \mathrm{~m}$, using various site exploration engineering techniques. Also 2 more samples from dump-1 was collected to analyze characteristics before and after treatment with "ferrous sulphate" and all these samples were properly coded. Thus a total of 29 samples were collected from the 3 different dumps. These samples were leaching and joining the nearby watercourse thereby causing surface and ground water pollution in the area. The collected samples were analyzed for the following four types of analysis:

\subsubsection{Physical Analysis}

The physical analysis was carried out as per the standard laboratory procedures for the parameters (i) Physical State, (ii) Color and Texture, (iii) Specific Gravity, (iv) Bulk Density, (v) Moisture / Loss on drying at $105^{\circ} \mathrm{C}$, (vi) Organic content / Loss on ignition at $550^{\circ} \mathrm{C} \&$ (vii) Extractable Lipophilic content

\subsubsection{Chemical Analysis}

The chemical analysis was carried out for calculating the inorganics. The hazardous nature of metals was estimated by digesting the metals with Tri-acids and analyzed by Atomic absorption spectrophotometer for the parameters (i) Chromium Hexavalent, (ii) Mercury and its compounds, (iii) Cadmium, (iv) Arsenic and its compounds, (v) Chromium (III) compounds, (vi) Copper and its compounds, (vii) Lead and its compounds, (viii) Molybdenum compounds, (ix) Nickel compounds, (x) Zinc compounds \& (xi) Barium compounds except Barium Sulphate.

\subsubsection{Toxicity Characteristic Leaching Procedure}

\section{(TCLP) Analysis}

The TCLP analysis was carried out to predict the leach chemical into ground water using acetic acid and $\mathrm{NaOH}$ as extraction fluid for the parameter (i) Chromium.

\subsubsection{Acceptance Criteria Analysis}

The acceptance criteria analysis into secured land fill was carried out to predict the leach chemical into ground water using water as extraction fluidfor the parameters (i) $\mathrm{pH}$ (corrosivity), (ii) Arsenic, (iii) Lead, (iv) Cadmium, (v) Chromium Hexavalent, (vi) Total Chromium, (vii) Copper, (viii) Nickel, (ix) Mercury, (x) Zinc, (xi) Fluorides, (xii) Ammonia, (xiii) Cyanide \& (xiv) Nitrates

\subsubsection{Experimentation Of Pretreatment Of Waste In}

\section{Laboratory}

Wastes not accepted for direct disposal into landfill shall have to either be treated before disposal into a landfill, or would have to be incinerated. Waste treatment is a process designed to convert hazardous wastes in the form of non-aqueous liquids, semi-solids or reactive solids into less leachable solids that can then be deposited directly into the secured landfill in compliance with the concentration limits/ criteria stipulated.

In the present case, the residue generated from the process (78.83 Tons/Day) is partly used in the process (50 Tons/Day) and the remaining (28.83 Tons/Day) need to be pretreated before keeping in secured landfill, otherwise the water-soluble chromium compounds cause surface and ground water pollution in the area, as being done in the present site. The dump samples collected at 27 places were analyzed to assess the hazardous waste potential. It is found that the main pollutant hexavalant chromium is ranging from 1852 to 4115 $\mathrm{mg} / \mathrm{kg}$ in dump - 1, ranging from 1777 to $3596 \mathrm{mg} / \mathrm{kg}$ in dump - 2 and ranging from 2597 to $9180 \mathrm{mg} / \mathrm{kg}$ in dump - 3 against the regulatory standard of $50 \mathrm{mg} / \mathrm{kg}$. Hence, there is an immediate necessity of conversion of hexavalent chromium to regulatory standards by using suitable reductant like Ferrous Sulphate $\left(\mathrm{FeSO}_{4}\right)$ to convert the hexavalent chromium to regulatory standards and relocate the waste to suitable landfill.

\subsubsection{Pretreatment with Ferrous Sulphate}

The usage of ferrous sulphate is preferred as pretreatment material to convert hazardous hexavalent chromium to regulatory standards, as it is cheap and locally available. The advantages of experimental results are used to develop a pretreatment process for Hexavalent Chrome Waste generated from Chromium Chemicals Manufacturing process and also used in chemical reducing process resulting in complete elimination of hexavalent chromium below detectable limit. Residue being highly porous and of fineness as low as 200 mesh readily and completely reacts with Ferrous Sulphate reducing agent forming trivalent chromium compounds which are in soluble above $\mathrm{pH}$ value 4 .

\subsubsection{Experimental Data and Observations}

As mentioned above trails were carried out under different variables of acid and Ferrous Sulphate solution and results are recorded as shown in Table 1. 
Table 1 Experimental data using sulphuric acid and ferrous sulphate.

\begin{tabular}{|c|c|c|}
\hline Observations & $\mathrm{pH}$ & $\begin{array}{l}\mathrm{Cr}^{+6} \text { in TCLP } \\
\text { Extract } \mathrm{mg} / \mathrm{lit}\end{array}$ \\
\hline Residue as it is & 12.2 & 122 \\
\hline $\begin{array}{l}\text { Hot water wash and acid washed } \\
\text { residue ( } 2 \% \text { Acid) } 1 \mathrm{~kg} \text { grind for } 2 \\
\text { hours discharge and store over night }\end{array}$ & 7.2 & 67 \\
\hline $\begin{array}{l}\text { Acid wash residue } 1 \mathrm{~kg} \text { grind for } 1 \\
\text { hour continue grinding for one more } \\
\text { hour during which add } 600 \mathrm{ml} 50 \% \\
\text { wt/vol } \mathrm{FeSO}_{4} \text { solution discharge and } \\
\text { store over night. }\end{array}$ & 6.4 & $\overline{B D L}$ \\
\hline Repeat above trail & 6.3 & $\overline{\mathrm{BDL}}$ \\
\hline $\begin{array}{l}\text { Repeat above trail with } 500 \mathrm{ml} \text { of } \\
50 \% \mathrm{FeSO}_{4} \text { solution }\end{array}$ & 6.8 & 5.0 \\
\hline $\begin{array}{l}1 \mathrm{Kg} \text { of hot water wash residue no } \\
\text { acid wash given grind for } 1 \text { hour. } \\
\text { Continue grinding and add } 600 \mathrm{ml} \text { of } \\
50 \% \mathrm{FeSO}_{4} \text { solution while grinding } \\
\text { for one more hour discharge and } \\
\text { store for over night. }\end{array}$ & 7.2 & 11.0 \\
\hline Repeat trail No: 3 & 6.1 & BDL \\
\hline $\begin{array}{l}\text { Hot water wash and acid washed } \\
\text { residue }(5 \% \text { Acid) grind for } 1 \text { hour } \\
\text { continue grinding and add } 500 \mathrm{ml} \text { of } \\
50 \% \mathrm{FeSO}_{4} \text { solution for } 1 \text { hour } \\
\text { discharge and store over night. }\end{array}$ & 6.8 & 5.0 \\
\hline
\end{tabular}

\subsubsection{Implementation On Plant Scale}

Depending on the above lab scale pretreatment methodology, the same pretreatment is designed for implementation on plant scale.

\subsubsection{Conceptual Design of Landfill Cells}

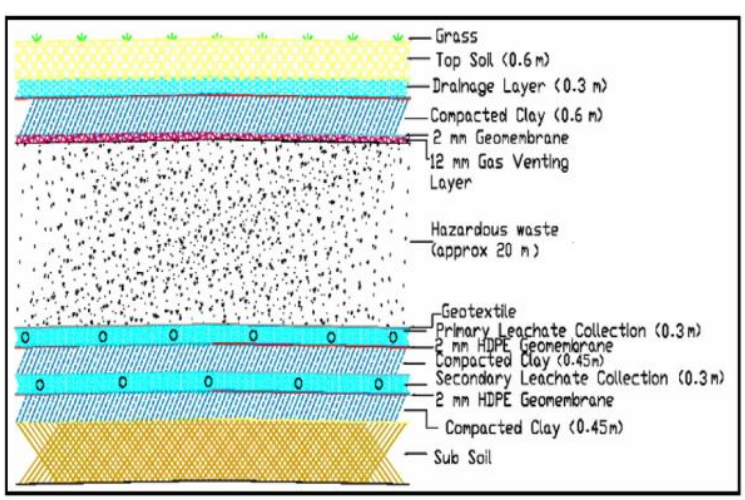

Figure1 Proposed Hazardous Waste secured landfill cross section

It is proposed to handle 35 Tons of hazardous waste and place it in secured landfill. The density of the solid waste is about $1.5 \mathrm{Tons} / \mathrm{m}^{3}$ and the total volume of the waste to be transported will be about $24 \mathrm{~m}^{3} /$ day. Hence, the annual waste handled will be on an average of 12,000 to 13,000 Tons. The facility proposed, is to be developed and established in an area of 5 acres only. Table 2 Hazardous waste secured landfill cross section

\subsection{Design Details}

Table 2 Hazardous Waste secured landfill cross section

\begin{tabular}{|l|l|}
\hline Design Parameters & Design Values \\
\hline Life of Landfill & $: 35$ years \\
\hline $\begin{array}{l}\text { Recommended Liner } \\
\text { Thickness }\end{array}$ & $: 1.5 \mathrm{~mm}$ \\
\hline Thickness being used & $: 2 \mathrm{~mm}$ \\
\hline $\begin{array}{l}\text { Estimated average density of } \\
\text { the waste }\end{array}$ & $: 1.5 \mathrm{Tons} / \mathrm{m}^{3}$ \\
\hline $\begin{array}{l}\text { Quantity of waste to be } \\
\text { disposed in Landfill }\end{array}$ & $: 53,000$ Tons \\
\hline $\begin{array}{l}\text { Intermediate soil cover }(20 \% \\
\text { of total Volume) }\end{array}$ & $: 10,600$ Tons \\
\hline Total volume of Landfill & $: 63,600$ Tons \\
\hline Density of clay & $: 1.9$ Tons $/ \mathrm{m}^{3}$ \\
\hline Soil Cover & $: 0.6 \mathrm{~m}$ \\
\hline Cover material & $:$ HDPE, $2 \mathrm{~mm}$ thick \\
\hline Volume of Waste & $: 24 \mathrm{~m}^{3} /$ day \\
\hline Area Required & $: 5$ Acres \\
\hline Quantity of Waste & $: 35$ Tons/day \\
\hline Annual Waste & $: 12,000$ to 13,000 Tons \\
\hline
\end{tabular}

The requirements for the grading of the base will restrict the maximum size of each cell to about $50 \mathrm{~m}$. To optimize the amount of fill placed relative to the area of liner required a typical cell is envisaged to be about $50 \mathrm{~m}$ wide by $75 \mathrm{~m}$ long. Two cells constructed side by side may be covered by a single capping to maximize the amount of waste disposed.

\section{RESULTS AND DISCUSSIONS}

The results of experimental investigation of comparison between leachate quality of chromium for the same depth of hazardous waste from Dump-1, Dump-2 and Dump-3 are plotted in comparative form and the following are the observations from the results of all three dumps: As seen from the results that the samples are mostly inorganic in nature. However, moisture content is present in most of the samples ranging from $5.18 \%$ to $8.93 \%$ due to rains and there is necessity of covering the dumps to reduce the leachate generation. The volatile solids are also varying from $6.33 \%$ to $8.96 \%$. The hazardous nature of metals were calculated by digesting the metals with Tri acids and analyzed by Atomic absorption spectrophotometer and Inductively Coupled Plasma Analyzer (ICPA).

The metals analyzed are Chromium Hexavalent, Mercury and its compounds, Cadmium, Arsenic and its compounds, Total Chromium, Copper and its compounds, Lead and its compounds, Nickel compounds, Zinc compounds. The hexavalent chromium is ranging from $1852 \mathrm{mg} / \mathrm{kg}$ to 4644 $\mathrm{mg} / \mathrm{kg}$ in Dump - 1 and ranging from 1777 to $3596 \mathrm{mg} / \mathrm{kg}$ in Dump - 2 and 2597 to 9180 in Dump - 3. This clearly indicates that the values are 35 to 180 times higher than the limits. Similarly, the trivalent chromium also ranging from 23058 to $53160 \mathrm{mg} / \mathrm{kg}$ in Dump - 1 and 28578 to 45004 $\mathrm{mg} / \mathrm{kg}$ in Dump - 2 and 34553 to $42736 \mathrm{mg} / \mathrm{kg}$ in Dump - 3 showing 4.5 to 10.5 times higher than the stipulated limits. All other metals are found within limits.

As per the convention any hazardous waste exceeding the limits is to be tested for TCLP analysis. The test TCLP (Toxicity Characteristics Leaching Procedure) is one of the cumbersome tests and involves treatment of hazardous waste 
in acetic buffer at $5 \mathrm{pH}$ and shaking for continuous 18 hour cycle to stimulate the leaching conditions. This test indicates contamination of ground water due to leaching of toxic metals. The values of TCLP are ranging from $86 \mathrm{mg} / \mathrm{lit}$ to $596 \mathrm{mg} / \mathrm{lit}$ i.e., 17 to 120 times higher than the stipulated standard of $5.0 \mathrm{mg} / \mathrm{lit}$. As per the guidelines various parameters were analyzed to assess the suitability of hazardous waste into secured landfill. It was observed that the hexavalent chromium is ranging from 75 to $440 \mathrm{mg} / \mathrm{lit}$ that is exceeding by 150 to 885 times than stipulated limit of 0.5 $\mathrm{mg} / \mathrm{lit}$.

\subsection{Statistical Analysis}

Statistical analyses of the experimental results of all the three dumps were carried out for Coefficient of Determination $\left(\mathrm{R}^{2}\right)$, Standard Error (SE) and Root Mean Square Error (RMSE).

\subsection{Coefficient Of Determination}

Correlation coefficient $(\mathrm{R})$ is one of the widely used statistical parameter for the investigation of relationships between variables. The value varies from -1 to +1 . Square of the correlation coefficient is called coefficient of determination $\left(\mathrm{R}^{2}\right)$. It is equal to the percentage of variance in the criterion variable that is explained by variance of the predictor variable. Because of this physical interpretation, $\mathrm{R}^{2}$ is a meaningful indicator of the accuracy of prediction (McCuen, 1989). The value of $\mathrm{R}^{2}$ varies from 0.0 to 1.0 . Values closer to 1.0, indicate better performance results.

Coefficient of determination was carried out to compare leachate quality of chromium through TCLP and acceptance criteria analysis of hazardous waste from all the three dumps. The coefficient of determination value $\mathrm{R}^{2}$ is 0.901 for dump 1 , 0.896 for dump 2 and 0.999 for dump 3 are shown in Figure 2, 3,4 , which shows that the experimental results are closer to field conditions and there is a leachate contamination of ground and Surface water due to leaching of chromium from the hazardous waste dumps. Also comparison between leachate quality of chromium analyzed through TCLP chromium and acceptance criteria chromium for the same depth was made and the results show that the experimentation is close to field conditions. The standard error (SE) and root mean square error (RMSE) for leachate quality of chromium analyzed through TCLP analysis and acceptance criteria analysis were calculated for all the three dumps.

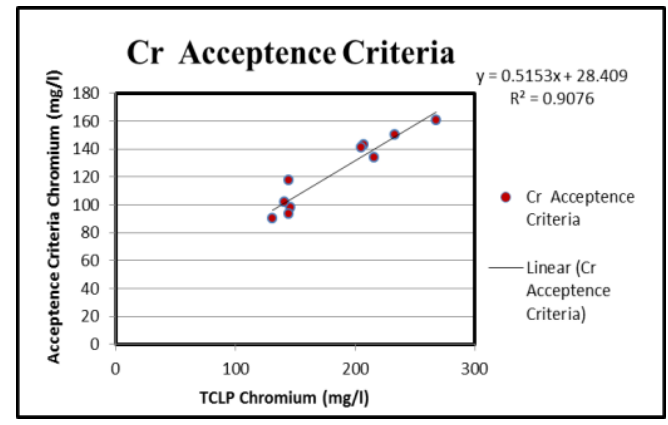

Figure 2 Comparision between leachate quality of chromium through TCLP and acceptence criteria analysis from hazardous waste dump-1

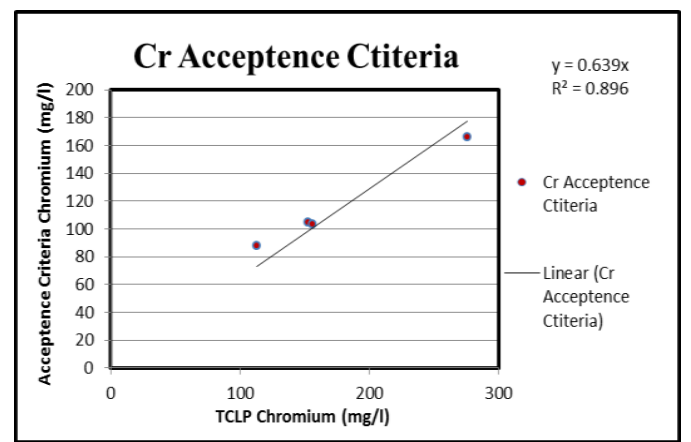

Figure 3 Comparision between leachate quality of chromium through TCLP and acceptence criteria analysis from hazardous waste dump-2

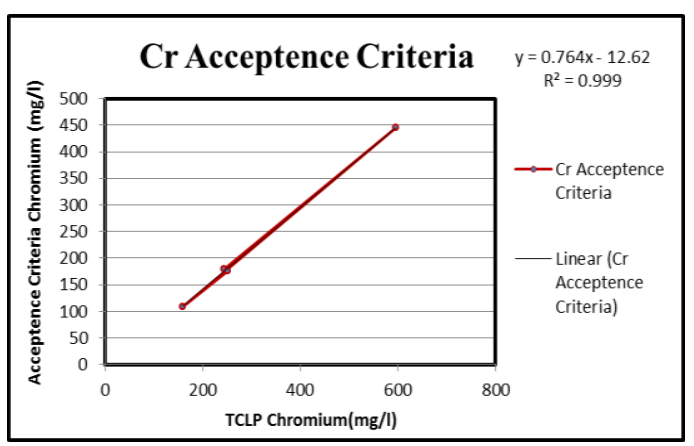

Figure 4 Comparision between leachate quality of chromium through TCLP and acceptence criteria analysis from hazardous waste dump-3

\subsection{Standard Error}

The standard error (S.E) is the estimated standard deviation or measure of variability in the sampling distribution of a statistic. Standard error is a statistical term that measures the accuracy with which a sample represents a population. In statistics, a sample mean deviates from the actual mean of a population; this deviation is the standard error. A low standard error means there is relatively less spread in the sampling distribution. The standard error for leachate quality of chromium analyzed through TCLP analysis and acceptance criteria analysis were calculated for all the 3 dumps. The standard error is 8.34 for dump I, 2.96 for dump II and 4.59 for dump III, which shows that the error in sampling and analysis was low. 


\subsection{Root Mean Square Error}

The Root Mean Square Error (RMSE) also called the root mean square deviation (RMSD) is a frequently used measure to predict the values of error from the data observed. The RMSE serves to aggregate all the mean errors into a single measure of predictive power. The Root Mean Square Error (RMSE) for leachate quality of chromium analyzed through TCLP analysis and acceptance criteria analysis were calculated for all the three dumps. The RMSE is 1.52 for dump 1, 0.04 for dump 2 and 1.77 for dump 3, which shows that the mean errors are less.

\section{CONCLUSIONS}

It is seen from the waste characterization results that the hazardous waste dumps have mainly very high values of Hexavalent Chromium and Trivalent Chromium compounds. The Hexavalent Chromium in the chromium dump of the present study indicates that it is 885 times above the Critical limit i.e., $0.5 \mathrm{mg} / \mathrm{l}$. It is observed from the pretreatment study that, the chrome waste with ferrous sulphate for converting the hexavalent chromium to trivalent chromium is producing favorable results. It is also evident from the plant scale operations of pretreatment that the Hazardous and toxic chrome waste can be converted into an inert, physically stable mass with very low leachability and sufficient strength to allow for landfilling using Ferrous Sulphate. The statistical analysis carried out for standard error, root mean square error static and coefficient of determination $\left(R^{2}\right)$ have shown reasonable results and also have good correlation between TCLP and acceptance criteria analysis. It is understand from the study that, the immediate attention is necessary for treatment and containment of hazardous chrome waste in an engineered landfill with double liner within the industry premises with leachate collection and environmental management, otherwise it will lead to heavy environmental pollution and the leachate of dumps having Hexavalent Chromium cause further contamination to surface and ground water of nearby area and agricultural fields.

\section{REFERENCES}

[1]. Andres, A., Ortis, I., Viguri, J.R., and Irabien, A. (1995). "Long-term behaviour of toxic metals in stabilized steel foundry dusts." J.Hazard. Mater., 40(1), 31-42.

[2].Cervinkova, M., Blaha, A., Meegoda, N.J., and Vondruska, M. (2005). "Long-term release of contaminants from solidified/stabilized waste". Int. Conf. Waste Eng05, Albi, France.

[3].Cervinkova, M., Blaha, A., and Meegoda, N.J. (2007). "Leaching of Heavy Metals Stabilized in Asphalt Matrix." Pract. Period. Hazard. Toxic Radioact. Waste Manage.,11(2), $106-113$.

[4].CPCB. (2001). Criteria for Hazardous Waste Landfills. HASWAMS/17/2000-01 Covers for Hazardous Waste Landfills. HAZWAMS/20/2001-02.

[5].CPCB. (2008). Guidelines for storage of incinerable hazardous wastes by the operators of common hazardous waste treatment, storage and disposal facilities and captive HW incinerators. HAZWAMS/2005-2006.

[6].McCuen, R.H. (1989). "Hydrologic analysis and design. Prentice-hall, New Jersy.

[7].Mitchel, J.K., and Madsen, F.T. (1987). Chemical effect on clay hydraulic conductivity. R.D Woods (ed.), New York.

[8]. MoEF. (1989). Hazardous Waste (Management and Handling) Rules. Official Gazette Publication, Government of India, New Delhi.

[9].MoEF. (2009). State of Environment Report India 2009. Government of India, New Delhi.

[10].Moszkowicz, P., Sanchez, F., Barna, R., and Mehu, J.(1998). "Pollutants leaching behavior from solidified wastes." Talanta, 46(3), 375 - 383.

[11].Onguro, V.O., and Inyang, H.O. (2003). "Relating batch and column diffusion coefficients for leachable contaminants in particulate waste materials". Environ. Eng., 129(10), 930942. 